\title{
At what carbon price forest cutting should stop
}

\author{
Timo Pukkala ${ }^{1}$
}

Received: 1 November 2019 / Accepted: 7 December 2019 / Published online: 13 February 2020

(C) The Author(s) 2020

\begin{abstract}
The carbon sink of boreal forests can be increased by paying forest landowners for carbon sequestration and taxing carbon releases. The aim of the study was to analyze the effect of carbon pricing on optimal forest management when forests are managed for maximal discounted benefits from timber production and carbon payments. A $0.5 \%$ random sample of all private forest stands of Finland was used in the analyses (48,842 stands). Calculations were performed for a 100 -year time horizon. It was assumed that the carbon balance (difference between sequestrated carbon and released carbon) in the forest (trees and soil) or the carbon balance of forestry (trees, soil and wood-based products) was subsidized (positive balance) or taxed (negative balance) by $0,50,100$ or $150 € \mathrm{t}^{-1}$, corresponding to $\mathrm{CO}_{2}$ prices of 0 , 13.6, 27.3 or $40.9 € \mathrm{t}^{-1}$, respectively. The results showed that paying forest landowners $150 € \mathrm{t}^{-1}$ of carbon sequestrated in forests would lead to the cessation of all cuttings everywhere in Finland for at least 100 years. In the northern part of the country, a carbon price of $100 € \mathrm{t}^{-1}$ would be enough to make the no-cutting management economically optimal. A low carbon price had the highest relative impact (value of
\end{abstract}

Project funding: This study was conducted in the FORBIO Project (Sustainable, climate-neutral and resource-efficient forest-based bioeconomy), funded by the Strategic Research Council of the Academy of Finland (decision number 314224) at the School of Forest Sciences, University of Eastern Finland.

The online version is available at http://www.springerlink.com

Corresponding editor: Lei Yu.

Timo Pukkala

timo.pukkala@uef.fi

1 University of Eastern Finland, Yliopistokatu 7, 80100 Joensuu, Finland increased sequestration divided by the cost of carbon payments). The benefit/cost ratio of carbon subsidies was higher in the northern part of boreal zone than in the southern parts. Subsidizing within-forest carbon sequestration by $50 € \mathrm{t}^{-1}$ would increase the carbon sequestration of Finnish forestry by $50 \%$, ranging from $36 \%$ (south Finland) to $116 \%$ (north Finland). A payment of $100 € \mathrm{t}^{-1}$ or more would increase carbon sequestration by $70 \%$, which is nearly the maximum possible increase that can be obtained by carbon subsidies.

Keywords Boreal forest $\cdot$ Carbon balance $\cdot$ Carbon sequestration · Carbon subsidies · Optimal forest management

\section{Introduction}

Forests sequestrate carbon from the atmosphere into the living biomass pool, from which it flows to the soil carbon pool in the form of litter, dead trees and harvest residues. A part of the carbon of cut trees goes to the carbon pool of woodbased products. The two first pools (living tree biomass and soil) are located in the same forest where the sequestration occurs whereas the third pool (wood-based products) is located elsewhere and may be distributed over wide areas, even over different continents.

Measuring the carbon sequestration of forests can be done by monitoring changes in the living biomass and in the dead organic matter (DOM). Of these, the amount of living biomass can be estimated easily and reliably, by using modern forest inventory methods and forest calculation systems (e.g., Siitonen et al. 2001; Pukkala 2004). There are also models for simulating changes in DOM, for example the Yasso07 and Yasso15 models (Ťupek et al. 2019). Since the soil carbon pool is more stable than the carbon pool of living 
biomass, it seems possible to develop reliable systems for crediting within-forest carbon sequestration.

Another basis of carbon credits would be the total carbon balance of forestry, including also the carbon balance of wood energy and wood-based products. Calculation of this balance includes more uncertainties, since the life spans of different products, their substitution factors, and uses of discarded products at the end of primary use are difficult to predict (Hurmekoski et al. 2020). Also the set of end products prepared of harvested wood may change, as well as the sources of energy that are used in product manufacturing.

If the carbon intake by photosynthesis is larger than the carbon releases of respiration and decomposition, the size of the carbon pool of living biomass and soil increases, and forests act as carbon sink. Calculating the carbon balance of whole forestry, including also wood-based products, is more complicated because, on one hand, harvesting and transport of wood as well as manufacturing and transport of woodbased products cause carbon releases but, on the other hand, the use of wood energy and wood-based products decreases carbon emissions into the atmosphere caused by the use of fossil energy and fossil-based products.

Recent research has shown that decreasing cuttings would increase the net biomass growth and carbon sequestration of Finnish forests (Heinonen et al. 2017; Pukkala 2018; Seppälä et al. 2019). This conclusion would hold for at least 100 years although decreasing cutting level would eventually lead to the decrease of the net growth of the living biomass and the increase of the DOM decomposition. Therefore, subsidizing carbon sequestration in forests would lead to decreased cutting level. Finnish forests are not very dense (the mean volume of productive forest is $118 \mathrm{~m}^{3} \mathrm{ha}^{-1}$ ) and most forests are rather young, the most common age class being 40-60 years (https://stat.luke.fi/sites/default/files/ metsavarat_2018_en_copy.pdf). Therefore, it seems evident that a high enough payment for carbon sequestration should lead to the cessation of almost all cuttings, at least for some decades (van Kooten et al. 1995).

Most studies on the effect of carbon price have been carried out at the stand level and mainly under even-aged forestry. The common result is that increasing carbon price increases optimal stand densities and postpones final felling (e.g., van Kooten et al. 1995; Guthrie and Kumareswaran 2009; Daigneault et al. 2010; Couture and Reynaud 2011; Pukkala 2011; Raymer et al. 2011; Assmuth and Tahvonen 2018). Increasing carbon price increases saw log harvests and decreases pulp wood removals (Pukkala 2011; Assmuth et al. 2017) and favors uneven-aged management (Pukkala et al. 2011; Assmuth and Tahvonen 2018). Pohjola et al. (2018) found that the temporal distribution of the effect of carbon crediting depends on carbon price, low payments having mild but long-lasting impacts. Allowing harvest level to vary in response to carbon pricing results in larger increases in carbon sequestration than maintaining a predetermined harvest level (Sjølie et al. 2013).

The inclusion of the carbon balance of wood-based products makes conclusions more complicated since the use of wood-based energy and wood-based products decreases emissions from fossil fuels. However, it is likely that subsidizing the carbon sequestration of the whole production and life cycle of wood-based products (including wood production in forests, harvesting, transport, manufacturing and cascade use of products) would also decrease optimal cutting levels (Heinonen et al. 2017; Seppälä et al. 2019), but most probably less than in the case where only withinforest carbon sequestration is subsidized. Price and Willis (2011) concluded that including all carbon effects results in only slightly longer rotations than those based only on timber value. Considering only forest carbon in calculations increases optimal rotations more than including all carbon effects (Price and Willis 2011; Pukkala 2011; Raymer et al. 2011).

Even if the basis of carbon credits is within-forest sequestration, the effects of this policy instrument should be evaluated in terms of the total carbon balance of forestry, i.e., including also the carbon balance of products. Otherwise, the analysis gives a biased picture on the effect of carbon crediting on climate change mitigation.

The effect of carbon pricing may be different at different latitudes or on different growing sites (Backéus et al. 2006). For example, it might be hypothesized that refraining from cuttings can be continued for longer in northern latitudes (or on poor sites) where trees grow slowly and can reach old ages, and the decomposition rate of DOM is slow.

Considering all these aspects, the aim of the study was to provide a forest level analysis on the effect of carbon pricing on optimal cutting level at different latitudes of boreal region. It was hypothesized that maximizing the total economic benefit from timber sales and carbon credits might lead to solutions where it is optimal to concentrate on timber benefits in the southern part of boreal forest and carbon credits in the north. If, under these circumstances, it is required that forests should provide an even flow of wood for the society, it seems likely that the optimal cutting level has unequal geographical distribution, which might also change in time. Also this question was addressed by this study.

\section{Materials and methods}

\section{Materials}

Stand level forest data for the private forests of Finland are currently available at www.metsaan.fi/paikkatietoaineistot. These data are based on airborne laser scanning (ALS) forest inventory. The available site attributes include land 
use category (productive forest, stunted forest, wasteland, other), soil type (mineral soil, spruce mire, pine bog), fertility class (mesotrophic, herb-rich, mesic, sub-xeric, xeric, barren heath), altitude, latitude and longitude. The growing stock attributes include stand basal area, number of trees per hectare, stand age, mean diameter and mean height. These variables are available for the total growing stock and separately for different main species and canopy layers. The total number of stands for which data are available is about 9.8 million.

A $0.5 \%$ random sample of stands available at www. metsakeskus/paikkatietoaineistot was selected for this study. Sampling was conducted separately for the following latitudinal ranges: $<62^{\circ}$ (referred to as "south"), $62^{\circ}-64^{\circ}$ (south-central), $64^{\circ}-66^{\circ}$ (north-central) and $>66^{\circ}$ (north). The total number of stands in the four samples was 48,842 (Table 1), ranging from 5283 (north) to 19,759 (south-central) and the total area of the stands was 66,374 ha. This area represents "the forestry land", which is divided into three productivity categories: productive forest (also called forestland), stunted forest and wasteland. The proportion of productive forest decreased from the $96 \%$ of south (latitude $<62^{\circ}$ ) to the $73 \%$ of north (latitude $>66^{\circ}$ ). The proportion of peatland forests was largest $(28 \%)$ in north-central Finland and smallest (11\%) in south Finland.

The mean growing stock volume decreased from the $150 \mathrm{~m}^{3} \mathrm{ha}^{-1}$ of south Finland to $60.4 \mathrm{~m}^{3} \mathrm{ha}^{-1}$ in the north. The proportion of pine increased towards north. Mesic and sub-xeric sites were the most common fertility classes everywhere. The proportion of mesic sites decreased and the proportion of sub-xeric sites increased from south to north.

The estimated initial soil carbon stock $\left(\mathrm{t} \mathrm{ha}^{-1}\right)$ of the sampled stands was larger than the carbon stock of living tree biomass (Table 1). The size of soil carbon pool was large especially on peatland sites. In Table 1, the mean soil carbon stock of peatland forests is the same in all four geographical regions. The carbon stock of peat was calculated from the thickness and density of the peat layer and the carbon content of peat. Since no stand-level data on the thickness of peat was available, average peat depth was used for all peatland stands: $69 \mathrm{~cm}$ for spruce mire and $152 \mathrm{~cm}$ for pine bog (Korhonen et al. 2013). The dry density of peat was assumed equal to $0.082 \mathrm{t} \mathrm{m}^{-3}$ on undrained peatland and $0.133 \mathrm{t} \mathrm{m}^{-3}$ on drained peatland (Minkkinen and Laine 1997).

It should be noted that only the aerobic surface layer of the peat affects the carbon dynamics of peatland forests. The thickness of the aerobic peat layer mainly depends on ditching and transpiration of the trees. Therefore, lacking information on peat thickness has very little effect on the soil carbon balance estimates of peatland forests.

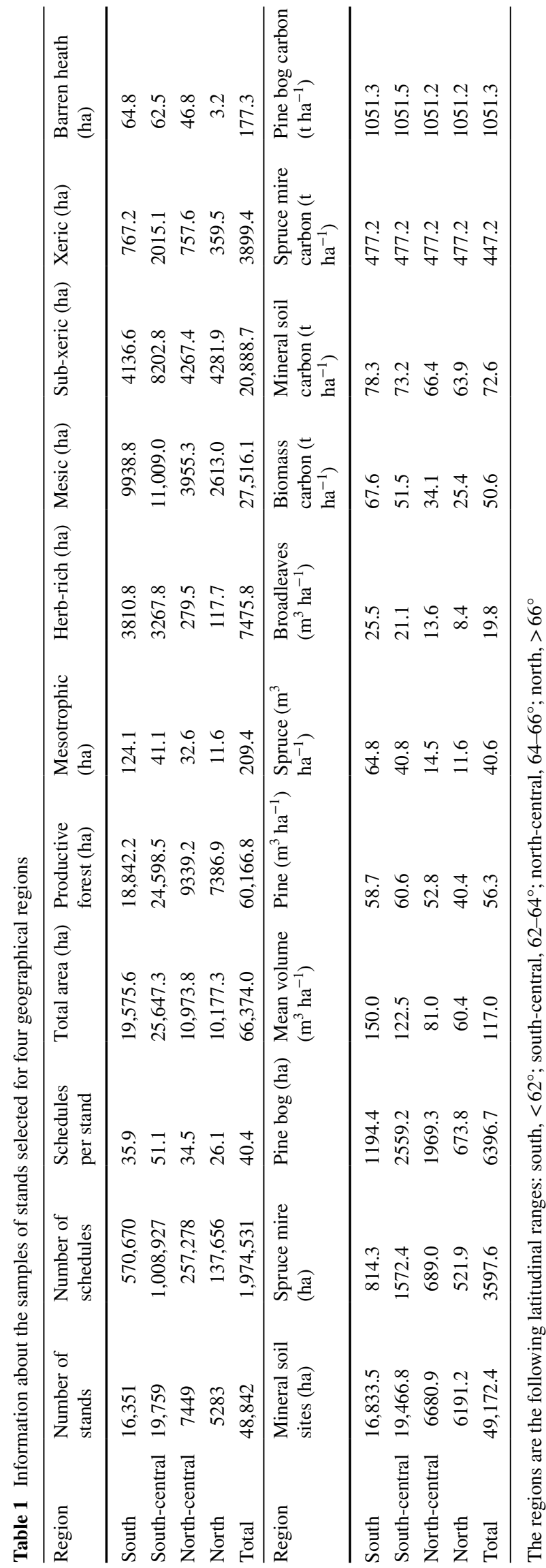




\section{Methods}

\section{Simulation of treatment alternatives for stands}

The calculations were done in two steps. First, a set of different treatment schedules were simulated for the stands for 100 years, divided into ten 10 -year periods. Then, optimal combinations of simulated treatment schedules were found by maximizing timber, carbon or total benefit with or without harvest volume constraints.

The stand data sampled from the national database were imported to the Monsu forest planning system, which has tools for both simulation and optimization (Pukkala 2004). The stand data imported to the Monsu forest planning system were used to generate five representative trees per species and canopy layer (see Pukkala and Miina 2005; Palahí et al. 2006 for details). The list of representative trees was used in the simulation of stand dynamics. Diameter increment, competition-induced "regular" mortality and advance regeneration (ingrowth) were simulated using the models of Pukkala et al. (2013). Mortality and cuttings decreased the frequencies of representative trees or removed them completely while regeneration and ingrowth resulted in new representative trees.

In the alternative treatment schedules, the simulation of cuttings was based on the recommended thinning basal area and regeneration diameter in even-aged forestry (Äijälä et al. 2014). The lower limits of the recommended ranges for thinning basal area and regeneration diameter were assumed to indicate the earliest moment of cutting. Other cutting schedules were produced by postponing the cuttings by one or several 10-year periods. To further increase the number of alternatives, schedules were simulated under the restrictions that cutting cannot be performed during the $1 \mathrm{st}, 2 \mathrm{nd}$, 3rd etc. 10-year periods, or during the first 10, 20, 30 etc. years.

Thinning treatments are implemented in various different ways in current Finnish forestry, ranging from the traditional thinning from below to thinning from above. The prevailing trend is to increase the use of thinning from above. To mimic this variation in thinning type, $1 / 3$ of stands was assigned to thinning from below (when a thinning was simulated, it was simulated as thinning from below), 1/3 to thinning from above, and 1/3 for uniform thinning (equal thinning intensity in all diameter classes). In thinning from above and from below, $50 \%$ of the removed basal area was taken by using equal thinning intensity in all diameter classes and the remaining 50\% was taken by removing the smallest (thinning from below) or largest (thinning from above) of the remaining trees. Only commercial trees (at least one pulpwood log could be prepared from the stem) were removed in cuttings.

In addition to final felling and thinning, also the removal of upper canopy was simulated in two-storied stands. This was the first option always when the stand had a dense enough understory that consisted of economically valuable species that were suitable to the fertility class of the site (Äijälä et al. 2014). Final felling was simulated as clearcutting in mineral soils except for pine-dominated stands on xeric sites and all peatland forests where natural regeneration was used.

Thinning from above reduces the mean tree diameter and postpones the time point of final felling. If the stand has much variation in tree diameter and well-developed advance regeneration, the final felling might be postponed for decades and might not be simulated at all during the 100 -year period. Applying thinning from above therefore converts the silvicultural system towards continuous cover management. Thinning from above gives a higher percentage of saw logs, and it has been found to result in better carbon balance than thinning from below (ZubizarretaGerendiain et al. 2016; Díaz-Yáñez et al. 2019).

Harvested trees were divided into timber assortments using the taper models of Laasasenaho (1982) and the minimum dimensions shown in Table 2. A part of the saw log volume, obtained from the taper model, was transferred to pulpwood volume, due to assumed quality defects. The percentage of saw log reduction was calculated, separately for each harvested tree, with the models of Mehtätalo (2002). However, since these models have been found to overestimate the reduction in conifers and underestimate it in broadleaves, the predicted relative reductions were
Table 2 Timber assortments

\begin{tabular}{|c|c|c|c|c|c|c|c|c|c|}
\hline \multirow[t]{2}{*}{ Species } & \multicolumn{3}{|c|}{ Road side price $\left(€ \mathrm{~m}^{-3}\right)$} & \multicolumn{3}{|c|}{ Minimum top diameter $(\mathrm{cm})$} & \multicolumn{3}{|c|}{ Minimum log length (m) } \\
\hline & Saw log & Small log & Pulpwood log & Saw log & Small log & $\begin{array}{l}\text { Pulp- } \\
\text { wood } \\
\text { log }\end{array}$ & Saw log & Small log & $\begin{array}{l}\text { Pulp- } \\
\text { wood } \\
\log \end{array}$ \\
\hline Pine & 57 & 32 & 30 & 15 & 13 & 8 & 4.3 & 3.4 & 3 \\
\hline Spruce & 50 & 32 & 30 & 16 & 13 & 9 & 4.3 & 3.4 & 3 \\
\hline Birch & 45 & - & 30 & 17 & - & 8 & 3.4 & - & 3 \\
\hline Aspen & 40 & - & 20 & 17 & - & 8 & 4.3 & - & 3 \\
\hline Alder & - & - & 10 & - & - & 8 & - & - & 3 \\
\hline
\end{tabular}


multiplied with the following correction factors (Malinen et al. 2007): pine 0.7, spruce 0.4, broadleaves 1.2 .

Simulation of clear-felling led to a series of other treatments. Cleaning of regeneration site was simulated if there were many small, non-commercial trees in the stand. Site preparation and planting or seeding were simulated after clear felling. Sowing of pine seeds was simulated only on sub-xeric mineral soil sites. Planting was assumed in all other cases. The planted species was selected randomly using the following probabilities: mesotrophic and herb-rich site, spruce 0.8 and silver birch 0.2 ; mesic site, pine 0.3 , spruce 0.6 and silver birch 0.1 . After planting, the tending treatments of the plantation included weeding in the most fertile sites, and one or two pre-commercial thinnings of the newly established young forest.

The total number of different treatment schedules simulated for the 48,842 stands was nearly two million $(1,974,531)$. The average number of different schedules per stand was 34.9 for south, 51.1 for south-central, 34.5 for north-central and 26.1 for north Finland (Table 1).

The net incomes from cuttings were calculated by multiplying the roadside prices of different timber assortments (Table 2) by their volumes, and subtracting the harvesting costs from the roadside prices. Harvesting costs were calculated using the time consumption functions of Rummukainen et al. (1995) for harvester and forwarder, and hourly cost of $90 € \mathrm{~h}^{-1}$ for harvester and $65 € \mathrm{~h}^{-1}$ for forwarder. The costs of silvicultural treatments are shown in Table 3.

\section{Carbon balance of tree biomass}

The stand-specific carbon pools of living biomass were initialized by applying the biomass models of Repola et al. (2007) and Repola (2009) for the representative trees used in simulation. For each of them the biomass of stem, stump, roots, branches and foliage was calculated. A species-specific carbon fraction of $0.505-0.519$ was used. The biomass of fine roots (diameter less than $2 \mathrm{~mm}$ ), for which no biomass model was available, was assumed to be related to foliage biomass: fine root biomass was $25 \%$ of foliage biomass in spruce and $67 \%$ of foliage biomass in pine and broadleaves (Helmisaari et al. 2007; Pukkala 2014).

Table 3 Costs of silvicultural treatments

\begin{tabular}{ll}
\hline Treatment & Cost $\left(€ \mathrm{ha}^{-1}\right)$ \\
\hline Cleaning of clear-felling site & 200 \\
Site preparation & $330-385$ \\
Seeding & 257 \\
Planting & 523 \\
Weeding & 250 \\
Pre-commercial thinning & $354-434$
\end{tabular}

The carbon balance of living tree biomass was calculated as the change in size of the carbon pool of the living biomass by considering, as input, predicted growth of tree biomass and the biomass of regeneration and ingrowth and, as output, harvested trees (including trees removed in pre-commercial thinning) and mortality. Living trees loose carbon also in litter (mainly from roots, branches and foliage). However, calculation of the carbon balance of living tree biomass does not require separate estimation of litter since the net change in biomass is equal to gross growth of biomass minus litter. However, litter estimates were needed in the calculation of soil carbon balance.

\section{Soil carbon balance}

The soil carbon pools were initialized with the models of Pukkala (2014). These models are based on long-term simulations of stand development and carbon dynamics. The ending soil carbon pools of the simulations were modelled using site fertility, temperature sum and growing stock variables as predictors. Since decomposition was simulated by using the Yasso model, the dry mass of the soil organic matter components had to be calculated separately. Therefore, separate models were fitted for acid-, water-, and ethanol-soluble as well as non-soluble and humus components of soil organic matter (referred to as AWENH components).

Inputs to the soil carbon pool consisted of regular mortality, annual above- and below-ground litter, and the roots, stumps, branches, foliage and tops of harvested trees. Litter production was calculated from biomass using the turnover rates shown in Table 4 (Liski et al. 2006). Each dry matter input was partitioned into AWEN-components (Table 5) based on information available in the Yasso User's manual (Liski et al. 2009). In addition, coarse woody debris (stumps of dead and harvested trees, stems of dead trees) were divided into different sub-pools based on the breast height diameter (dbh) of the dead or cut tree since the decomposition rate depends on the size of the piece of dry matter, and large pieces (e.g. large stems) decompose more slowly than small ones (Tuomi et al. 2011).

Output from the soil carbon pool consisted of DOM decomposition simulated by using the Yasso07 model (Tuomi et al. 2011). Yasso07 was used instead of the newer

Table 4 Turnover rates (proportion of dry mass shed annually as litter)

\begin{tabular}{llll}
\hline Species & Foliage & $\begin{array}{l}\text { Branches and } \\
\text { coarse roots }\end{array}$ & Fine roots \\
\hline Pine & 0.3 & 0.0125 & 0.811 \\
Spruce & 0.2 & 0.0125 & 0.868 \\
Broadleaves & 1.0 & 0.0135 & 1.000 \\
\hline
\end{tabular}


Table 5 Proportions of different chemical components of litter

\begin{tabular}{|c|c|c|c|c|c|c|c|c|c|c|c|c|}
\hline \multirow[t]{2}{*}{ Chemical component } & \multicolumn{3}{|c|}{ Stem, stump, coarse root } & \multicolumn{3}{|c|}{ Branches } & \multicolumn{3}{|c|}{ Foliage } & \multicolumn{3}{|c|}{ Fine roots } \\
\hline & Pine & Spruce & Broadleaf & Pine & Spruce & Broadleaf & Pine & Spruce & Broadleaf & Pine & Spruce & Broadleaf \\
\hline Acid-soluble & 0.68 & 0.67 & 0.71 & 0.45 & 0.45 & 0.45 & 0.52 & 0.48 & 0.43 & 0.58 & 0.55 & 0.58 \\
\hline Water-soluble & 0.02 & 0.02 & 0.01 & 0.02 & 0.02 & 0.02 & 0.18 & 0.13 & 0.19 & 0.13 & 0.13 & 0.19 \\
\hline Ethanol-soluble & 0.01 & 0 & 0 & 0.08 & 0.08 & 0.08 & 0.09 & 0.07 & 0.10 & 0.06 & 0.07 & 0.06 \\
\hline Non-soluble & 0.29 & 0.3 & 0.28 & 0.45 & 0.45 & 0.45 & 0.21 & 0.32 & 0.28 & 0.23 & 0.25 & 0.23 \\
\hline
\end{tabular}

Yasso15 because the initialization models (Pukkala 2014) were based on simulations with Yasso07.

\section{Peatland carbon dynamics}

The carbon dynamics of woody materials (mortality, harvest residues, litter) was simulated in the same way in peatland and mineral soil forests. In peatland forests, the carbon dynamics of peat was simulated as an additional component. In undrained peatland sites the peat was expected to grow, corresponding to net increment in peat carbon stock of $0.25 \mathrm{t} \mathrm{C} \mathrm{ha}^{-1} \mathrm{a}^{-1}$ (Turunen et al. 2002; Ojanen 2015). If the site was ditched, it was assumed that peat does not grow.

The aerobic peat layer decomposes, releasing carbon dioxide to the atmosphere. The thickness of the aerobic layers depends on the depth and density of ditches as well as the transpiration of trees. In this study, the depth of the aerobic peat layer was calculated (Fig. 1) with the model of Sarkkola et al. (2010).

The amount of (non-wood) peat in the aerobic layer was calculated from peat density $\left(0.082 \mathrm{t} \mathrm{m}^{-3}\right.$ in non-drained and $0.133 \mathrm{t} \mathrm{m}^{-3}$ in drained peatland (Minkkinen and Laine 1997)) and thickness of the aerobic layer. Decomposition of aerobic peat was simulated by using the Yasso07 model and the following proportions of the AWENH components: pine bog A 0.040, W 0.005, E 0.005, N 0.600, H 0.350; spruce mire A 0.080, W 0.010, E 0.010, N 0.800, H 0.100. With these proportions, the simulated carbon releases from peat corresponded to reported releases, and releases were higher from fertile peatland sites (Sarkkola 2007; Ojanen et al. 2010).

\section{Product carbon dynamics}

Inputs to the product carbon pools consisted of harvested trees, which were firstly partitioned into two main timber assortments: saw log and pulpwood. Each assortment was further partitioned into five product categories (Table 6): long-term products (sawn wood, veneer and plywood), mechanical mass products, chemical mass products, "new products", and bioenergy. "New products" refer mainly to dissolving pulp products, for instance textiles made of

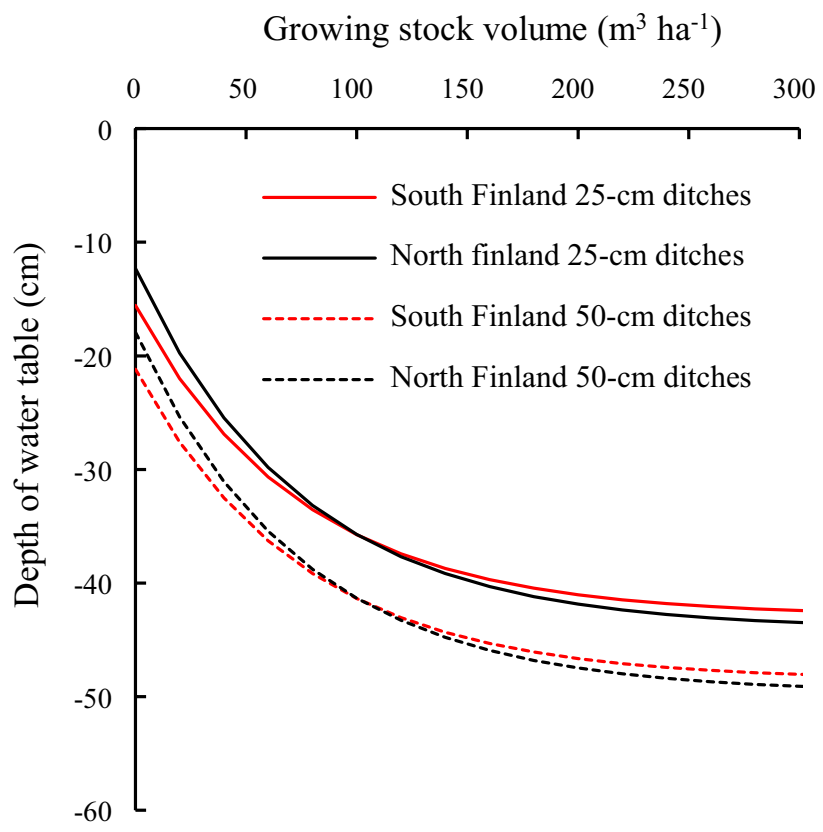

Fig. 1 Depth of water table in southern and northern Finland as a function of growing stock volume for two ditch depths according to the model of Sarkkola et al. (2010)

wood fibers. Figure 2 illustrates the partitioning of pine stem into different product categories.

The five product categories had different life spans (resulting in different disposal rates), manufacturing releases, substitution factors, and end-of-life uses (Table 7). The shares of product categories, their substitution factors and end-of-life parameters were based on the recent study of Hurmekoski et al. (2020). Otherwise, the product model used in this study was the same as explained in detail in Pukkala (2014). The initial sizes of the product carbon pools were predicted with simulationbased models (Pukkala 2014) developed in the same way as the models for initial soil carbon pools. It was assumed that the initial pool of new products was zero in all stands. The initial pools refer to the remaining amount of carbon in products prepared of wood harvested earlier from a particular stand. 
Table 6 Proportions of product types prepared of different timber assortments

\begin{tabular}{llllll}
\hline Assortment & $\begin{array}{l}\text { Sawn wood, } \\
\text { veneer, plywood }\end{array}$ & $\begin{array}{l}\text { Mechanical } \\
\text { mass products }\end{array}$ & $\begin{array}{l}\text { Chemical mass } \\
\text { products }\end{array}$ & New products & Bioenergy \\
\hline Pine saw log & 0.51 & 0.04 & 0.05 & 0 & 0.4 \\
Spruce saw log & 0.52 & 0.04 & 0.05 & 0 & 0.39 \\
Birch saw log & 0.34 & 0.05 & 0.07 & 0 & 0.54 \\
Aspen saw log & 0.05 & 0.025 & 0.025 & 0 & 0.9 \\
Pine pulpwood & 0 & 0 & 0.38 & 0 & 0.62 \\
Spruce pulpwood & 0 & 0.23 & 0.29 & 0 & 0.48 \\
Birch pulpwood & 0 & 0.12 & 0.08 & 0.18 & 0.62 \\
Other pulpwood & 0 & 0.1 & 0.1 & 0 & 0.8 \\
\hline
\end{tabular}

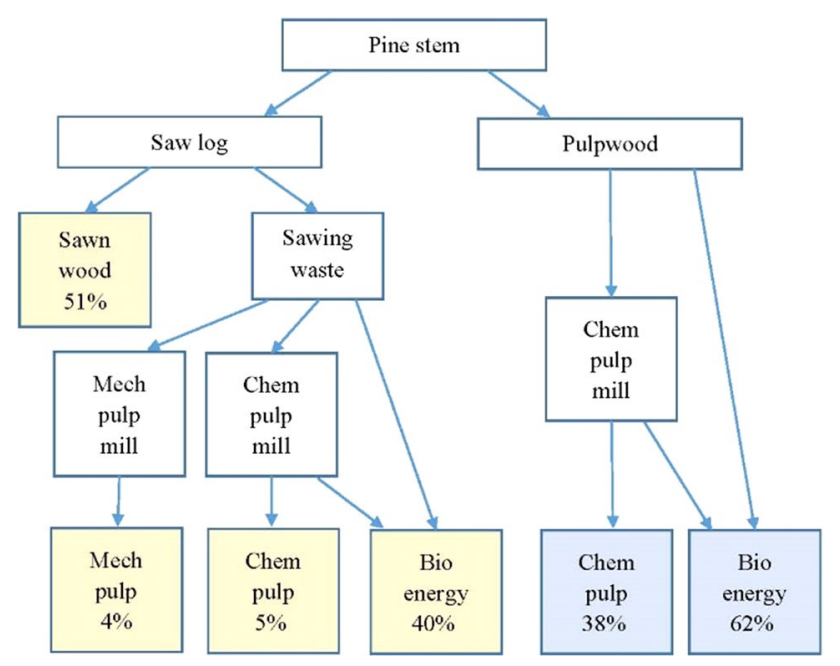

Fig. 2 Division of pine stems into different product categories (shaded boxes). The percentages in the shaded boxes were used in the calculations of this study (see Table 6). The proportions of saw log and pulpwood depended on the diameter and height of the stem

\section{Optimizations}

The objective variables considered in optimization were net present value $\left(€ \mathrm{ha}^{-1}\right)$ of timber production $\left(N P V_{\text {timber }}\right)$, net present value of carbon revenues $\left(N P V_{\text {carbon }}\right)$, and volume of harvested timber $\left(\mathrm{m}^{3}\right) . N P V_{\text {timber }}$ was calculated to infinity, by predicting the $N P V$ of the ending growing stock (at the end of the 100-year simulation period) with models (Pukkala 2005) and discounting it to the present.

Carbon revenues were calculated by multiplying the carbon balance (sequestration-release) of each 10-year period by the carbon price and discounting the product to the present from the middle of the 10 -year period. The following carbon prices were used to analyze the effect of carbon price on optimal cutting level: $0,50,100$ and $150 € \mathrm{t}^{-1}$. These prices correspond to $\mathrm{CO}_{2}$-prices $0,13.63,27.27$ and $40.91 € \mathrm{t}^{-1}$. Carbon revenues were calculated by using either within-forest carbon balance (carbon balance of living trees and soil) or total carbon balance of forestry (carbon balance of trees, soil and products) as the basis of carbon crediting.

Net present value was calculated with a 3\% discount rate. The current growing stock and harvest levels and the rotation lengths of Finnish forests correspond to those obtained by maximizing NPV with a $2-3 \%$ discount rate. Of this range, $3 \%$ was selected since it minimizes the effect of net incomes obtained after the 100-year simulation period on NPV. The 100 -year discount factor is 0.138 for a $2 \%$ rate but only 0.052 for a $3 \%$ rate.

The first part of the analysis concerned the evaluation of the trade-off between $N P V_{\text {timber }}$ and $N P V_{\text {carbon. }}$. This analysis was accomplished by maximizing the following utility function:

$$
\begin{aligned}
U= & w_{\text {timber }} N P V_{\text {timber }} / \operatorname{Max} N P V_{\text {timber }} \\
& +w_{\text {carbon }} N P V_{\text {carbon }} / \operatorname{Max} N P V_{\text {carbon }}
\end{aligned}
$$

Table 7 Parameters for the carbon dynamics of product categories

\begin{tabular}{lllll}
\hline Product categories & $\begin{array}{l}\text { Annual disposal } \\
\text { rate }\end{array}$ & $\begin{array}{l}\text { Production } \\
\text { release }\end{array}$ & $\begin{array}{l}\text { Substitution } \\
\text { factor }\end{array}$ & EOL reuse rate \\
\hline Sawn wood, veneer, plywood & 0.0198 & 0.04 & 1 & 0.9 \\
Mechanical mass products & 0.25 & 0.48 & 0 & 0.8 \\
Chemical mass products & 0.25 & 0.13 & 0.11 & 0.8 \\
New products & 0.25 & 0.05 & 2.57 & 0.2 \\
Bioenergy & 0.693 & 0.2 & 0.7 & 0 \\
\hline
\end{tabular}

$E O L$ end-of-life 
where $w_{\text {timber }}$ is the weight of timber benefit objective and $w_{\text {carbon }}$ is the weight of carbon benefit objective. $\operatorname{Max} N$ $P V_{\text {timber }}$ and $\operatorname{Max} N P V_{\text {carbon }}$ are the largest possible values (single-objective maxima) of $N P V_{\text {timber }}$ and $N P V_{\text {carbon, }}$, respectively.

Different points of the production possibility boundary (trade-off curve) were obtained by solving the problems with different weights for $N P V_{\text {timber }}$ and $N P V_{\text {carbon. }}$ The total NPV and the harvest level of every solution were recorded, making it possible to report the optimal harvest level (harvest level that maximized the total NPV) as a function of carbon price. These analyses were performed separately for the four geographical regions (south, south-central, north-central and north Finland).

An additional optimization was carried out where the total NPV (timber + carbon) was maximized with evenflow harvest constraint. The cutting level was the same as the average 10-year harvest in unconstrained optimization when the total NPV was maximized with a carbon price of $50 € \mathrm{t}^{-1}$. It was now required that the average unconstrained harvest level (2 $500000 \mathrm{~m}^{3}$ in 10 years) must be reached during every 10 -year period. This optimization corresponded to the requirement that forestry must produce a certain uninterrupted minimum supply of timber for forest industry. The purpose was to see if the optimal allocation of forests to carbon sequestration and timber production is different in different geographical regions.

\section{Results}

\section{Effect of carbon price on optimal cutting level}

Increasing weight on discounted carbon credits decreased the net present value of timber production (Fig. 3). Consequently, harvests also decreased. In the diagrams of Fig. 3, carbon credits were based on the total carbon balance of forestry, i.e., carbon balances of living tree biomass, forest soil, and wood products. Increasing carbon price decreased timber benefit in the production that maximized the total NPV (red triangles in the left panel of Fig. 3). Increasing carbon price also decreased the harvest level that maximized the total NPV (red triangles in the right panel of Fig. 3). This decrease was clearly faster in the northern parts of Finland.

Increasing carbon price decreased the optimal harvest level in all four geographical regions (Fig. 4). The decrease was fastest in the northern part of the country. When carbon credits were based on the total carbon balance of forestry (tree biomass, forest soils, products), the optimal harvest level was never zero (Fig. 4, top).

When carbon crediting was based on within-forest carbon balance (tree biomass and forest soil), the optimal cutting level of south and south-central Finland was zero when carbon price was $150 € \mathrm{t}^{-1}\left(40.91 €\right.$ per ton of $\left.\mathrm{CO}_{2}\right)$. In north and north-central Finland, it was optimal to stop cuttings already at carbon price of $100 € \mathrm{t}^{-1}$ (27.27 $€$ per ton of $\mathrm{CO}_{2}$ ). In the northern part of the country (latitude $\geq 66^{\circ}$ ), the lowest analyzed carbon price of $50 € \mathrm{t}^{-1}$ (13.64 $€$ per ton of $\mathrm{CO}_{2}$ ) reduced the optimal harvest level by almost $80 \%$.

\section{Effect of carbon pricing on carbon sink}

The cumulative carbon balance of forestry (forests and forest products) was positive in all regions when the total NPV was maximized without carbon credits (Fig. 5, blue lines). This means that forestry acted as carbon sink when the profitability of timber production was maximized without any constraints and without revenues from carbon sequestration. The rate of carbon sequestration decreased towards north. Carbon sequestration was about four times faster in the southern parts of Finland (latitude $\leq 62^{\circ}$ ) than in the northern parts (latitude $\geq 66^{\circ}$ ).

Increasing carbon price increased the rate of carbon sequestration in economically optimal management (where the total NPV from timber production and carbon revenues was maximized). When carbon credits were based on the total carbon balance (Fig. 5, left panel, Fig. 6), the highest price $\left(150 € \mathrm{t}^{-1}\right)$ increased carbon sequestration $43 \%$ in south, $59 \%$ in south-central, $106 \%$ in north-central and $132 \%$ in north Finland, compared to zero carbon price. In the southern parts of the country, the effect of carbon price was proportional to carbon price when the total carbon balance of forestry (products included) was credited. In northern Finland, increasing carbon price increased carbon sequestration at decreasing rate. In the northernmost part of the country (latitude $\geq 66^{\circ}$ ) increasing carbon price beyond $100 € \mathrm{t}^{-1}$ no longer increased carbon sequestration.

The maximal rate of carbon sequestration was reached with lower carbon price when carbon credits were based on within-forest carbon balance (carbon balance of products was not credited). The lowest analyzed carbon price of $50 € \mathrm{t}^{-1}$ improved the carbon balance of forestry (trees + soil + products) $36 \%$ in south, $43 \%$ in south central, $81 \%$ in north central and $117 \%$ in north Finland (Fig. 6). There were differences also in the temporal distribution of carbon sequestration, especially in southern parts of Finland. The results shown in Figs. 5 and 6 imply that crediting only within-forest carbon balance is more cost-efficient than crediting the total carbon balance of forestry. In the southern parts of Finland, a subsidy of $100 €$ per sequestrated ton of carbon was enough to get the maximum effect, and $50 € \mathrm{t}^{-1}$ was sufficient in northernmost Finland.

Assuming that the value of sequestrated carbon to society is 100 or $150 € \mathrm{t}^{-1}$ (27.3 or $40.9 € \mathrm{t}^{-1}$ of $\mathrm{CO}_{2}$ ), Fig. 7 illustrates the ratio between the value of increased sequestration and the cost of carbon subsidies. It can be seen that 
South Finland (latitude $<62$ degrees)

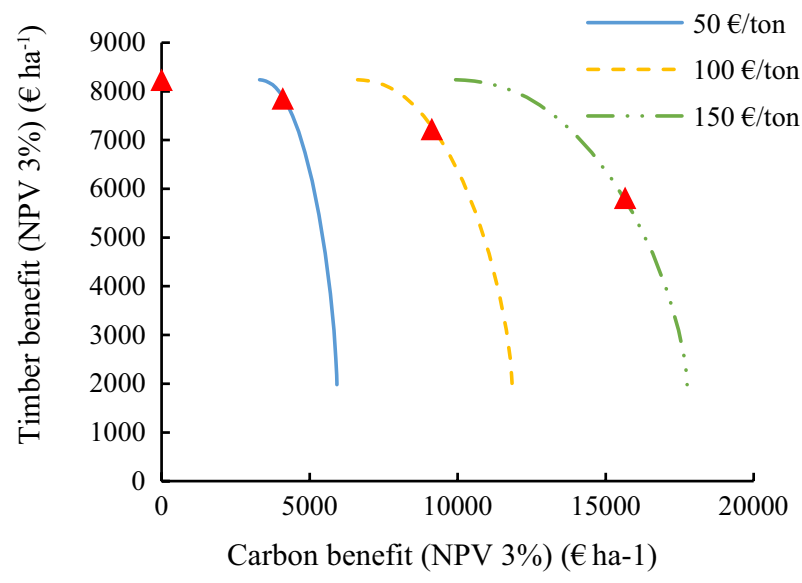

North Finland (latitude $>66$ degrees)

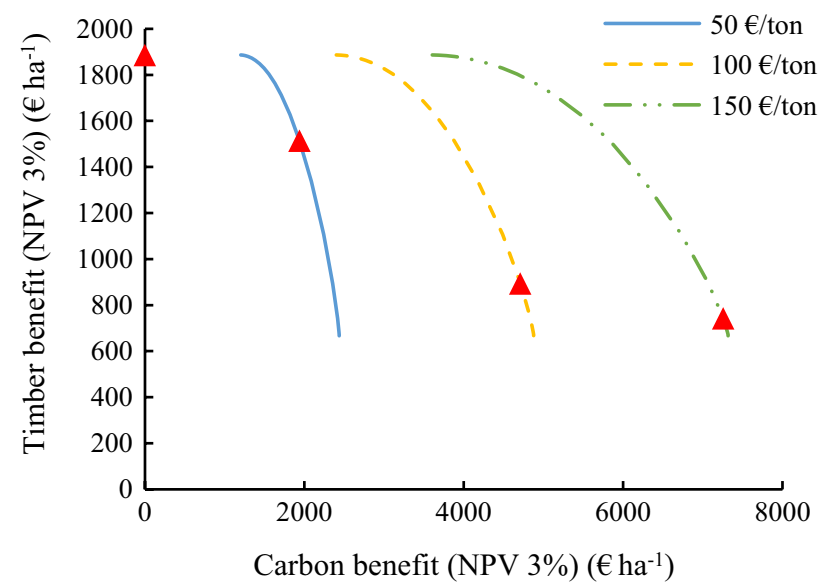

Fig. 3 Left: Trade-off curve between timber benefit $\left(N P V_{\text {timber }}\right)$ and carbon benefit $\left(N P V_{\text {carbon }}\right)$ with different carbon prices $\left(€ \mathrm{t}^{-1}\right.$ of carbon) in south (top) and north (bottom) Finland. Red triangles show the point where the total NPV is maximized. Right: optimal harvest level at different points of the trade-off curves (expressed as percent

the benefit/cost ratio was by far the highest for carbon price $50 € \mathrm{t}^{-1}$ and the ratio increased towards north. Therefore, the best relative return from carbon subsidies was obtained with low carbon price and in northern parts of the boreal zone. Increasing carbon price exhibited decreasing marginal effect.

\section{Optimal allocation of cuttings}

When the total NPV was maximized with even-flow cutting target, southern forests were cut more than their unconstrained average harvest level for 3-4 decades (Fig. 8). After the first decades, many cuttings were conducted in southcentral Finland, especially when carbon credits were based on the total carbon balance of forestry. In north-central and north Finland, cuttings were less than the long-term average of unconstrained harvests for 3-4 decades, after which
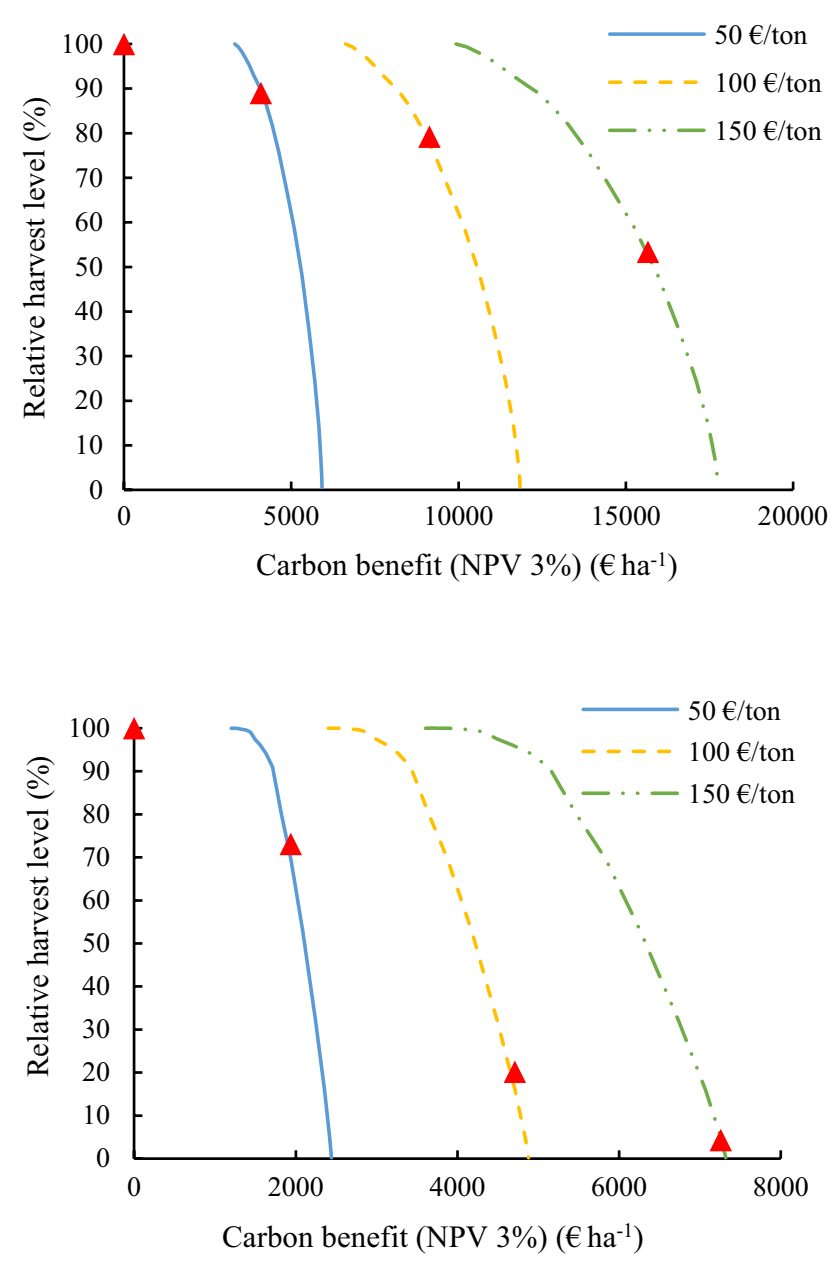

of optimal harvested volume with zero carbon price). Red triangles show the harvest level that maximizes the total NPV. The basis of carbon credits is the total carbon balance of forestry (trees, soil and products)

the cutting level was gradually increased. When carbon credits were based on the total carbon balance of forestry (trees + soil + products) the total harvest exceeded the required minimum of 2.5 million $\mathrm{m}^{3}$ during 10 -year periods $3-5$, the total harvest of these periods being $2.8-3.1$ million $\mathrm{m}^{3}$. When carbon credits were based on within-forest carbon balance, the total harvested volume never exceeded 2.5 million $\mathrm{m}^{3}$ per 10 years.

The harvests shown in Fig. 8 (left) led to increasing growing stock volume (Fig. 9). In south Finland, the volume first decreased slightly, after which it increased rapidly for the remaining part of the 100-year simulation period. In all other regions, the growing stock volume increased for 70-90 years, after which it decreased slightly. The average growing stock volume of whole Finland increased from 107 to $248 \mathrm{~m}^{3} \mathrm{ha}^{-1}$. 


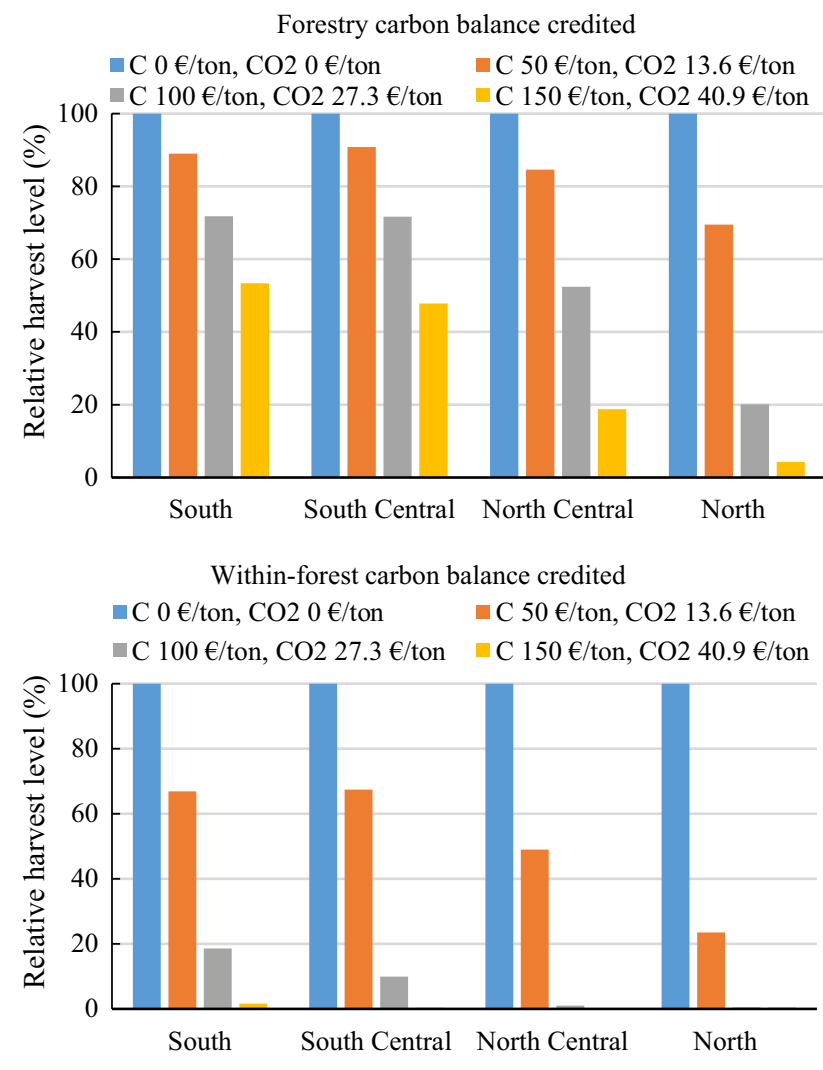

Fig. 4 Effect of carbon pricing on optimal cutting level in different parts of Finland when carbon credits are based on the total carbon balance of forestry (living tree biomass + forest soil + wood products) (top) or within-forest carbon balance (living tree biomass + forest soil) (bottom)

In all geographical regions, the volume of growing stock was increased beyond the level that maximized volume increment. The mean growing stock volume that maximized net volume increment was $125 \mathrm{~m}^{3} \mathrm{ha}^{-1}$ for north Finland and $200 \mathrm{~m}^{3} \mathrm{ha}^{-1}$ for south Finland. The decades during which volume increment was maximized, maximized also the rate of carbon sequestration from the atmosphere. Figure 9 shows that it was optimal to continue accumulating carbon into trees although this accumulation would led to forests that were too dense for the maximal net increment of stem wood volume.

\section{Discussion}

The study showed that paying forest landowners for carbon sequestration decreases optimal harvest level, most in north Finland. Crediting only within-forest carbon sequestration decreases optimal cutting level more rapidly than crediting the total carbon balance of forestry. This is mainly due to the fact that cutting trees for long-lasting wood products decreases emissions from fossil fuels and stores carbon for long times.

Measuring within-forest carbon balance is more reliable than measuring the total carbon balance of forestry, which includes several uncertainties related to product lifetime, substitution factors, end-of-life uses and sources of energy used in product manufacturing. Of the two sub-balances of within forest carbon sequestration, soil carbon balance is more difficult to calculate but it is also more stable and less affected by harvest level than the carbon balance of tree biomass. The carbon balance of tree biomass is the easiest to monitor, and it reacts most to changes in the cutting level.

Carbon crediting can be used as a political instrument. Crediting within-forest carbon balance is cheaper and more efficient than crediting the total carbon balance of forestry. A certain increase in carbon sequestration can be obtained at $50 € \mathrm{t}^{-1}$ lower carbon price (13.6 $€ \mathrm{t}^{-1}$ lower $\mathrm{CO}_{2}$ price) by crediting within-forest carbon sequestration instead of crediting the total carbon balance of forestry. The carbon sequestration of Finnish forests could be increased by $70 \%$ if forest landowners were paid $100 € \mathrm{t}^{-1}$ of carbon $\left(27.27 € \mathrm{t}^{-1}\right.$ of $\mathrm{CO}_{2}$ ) and forest were managed for the maximal discounted incomes from both timber production and carbon revenues. This increase would be reached with the same $\mathrm{CO}_{2}$ price as the $\mathrm{CO}_{2}$ price in the European Union Emissions Trading System carbon market in September 2019 (https://sandb ag.org.uk/carbon-price-viewer/). If this price reflects the true value of carbon sequestration, and Finnish forest landowners would get this compensation, it would be optimal to stop all cuttings in northern Finland for at least 100 years and reduce cuttings by $80-90 \%$ in the other parts of Finland.

A minimum cutting target of 2.5 million $\mathrm{m}^{3}$ in 10 years was used in one analysis of the current study. Since the calculations were based on a $0.5 \%$ sample from all stands of private forests, the 2.5 million $\mathrm{m}^{3}$ target corresponds to 50 million $\mathrm{m}^{3} \mathrm{a}^{-1}$ of usable timber (saw $\log$ and pulpwood) from private forests. With this minimum harvest, it would be optimal accumulate carbon in northern forests at first and start cuttings from the south. The optimal cutting level in north and north-central Finland (north of 64 degree's latitude) would be $50-70 \%$ of the long-term average for three decades, after which the harvest level should be gradually increased. The results showed that, if the forests should produce a certain supply of timber, it is not optimal to assign northern forests to carbon sequestration and southern forests to timber production. However, a step towards this type of allocation would be optimal for about 30 years.

A closer inspection of the results revealed that cuttings were concentrated in regions where saw $\log$ was available. This can be explained by the fact that cutting of saw logs and minimizing the cutting of pulpwood-sized trees increases both timber and carbon benefits. Harvested 
Fig. 5 Cumulative carbon balance of forestry (trees + soil + products) when the total NPV (timber + carbon credits) is maximized with a 3\% discount rate. Left: carbon credits are based on the total carbon balance of forestry (trees + soil + products); Right: carbon credits are based on within-forest carbon balance (trees + soil)
Forestry carbon balance credited
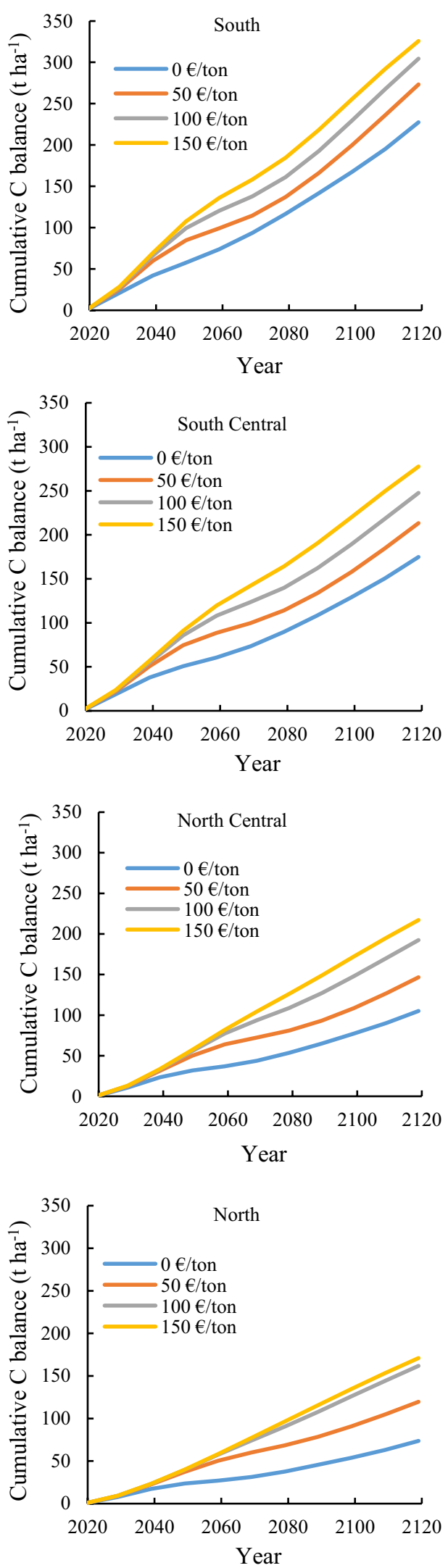

Within-forest carbon balance credited
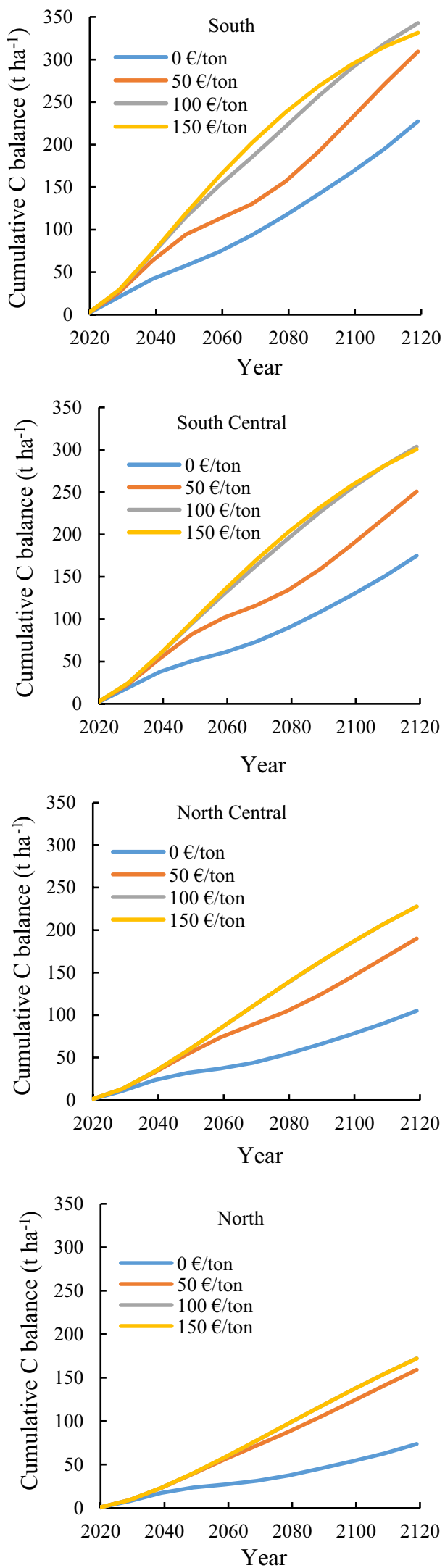
Fig. 6 Effect of carbon payments on the carbon balance of forestry (trees + soil + products) in different geographical regions and with different carbon prices (50, 100 or $150 € \mathrm{t}^{-1}$ of carbon)

Fig. 7 Benefit/cost ratio (value of additional carbon sequestration divided by carbon payment) in different geographical regions and with different carbon payments $(50,100$ or $150 €$ per ton of carbon) when the value of sequestrated carbon is 100 (top) or 150 (bottom) $€ \mathrm{t}^{-1}$
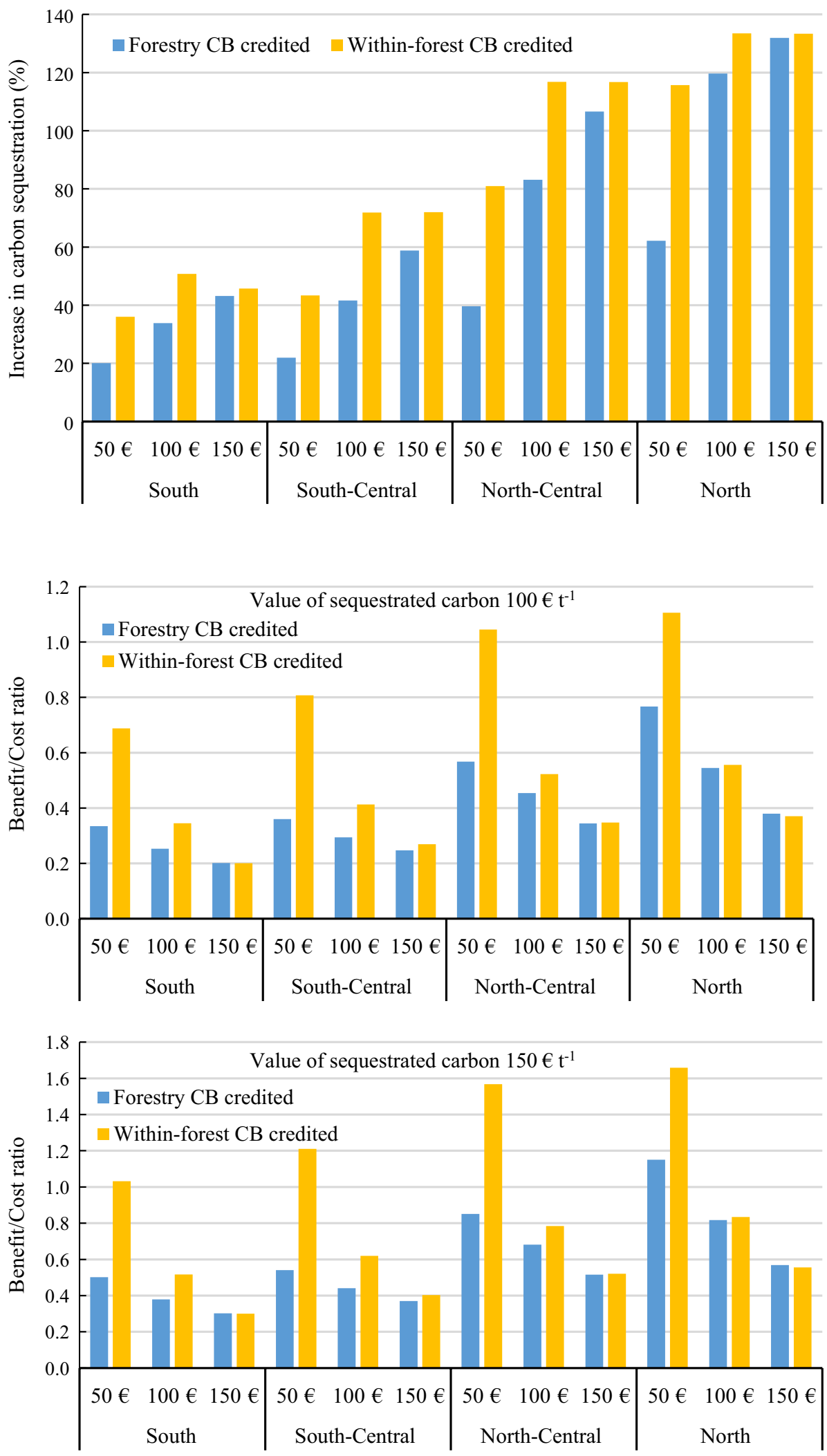

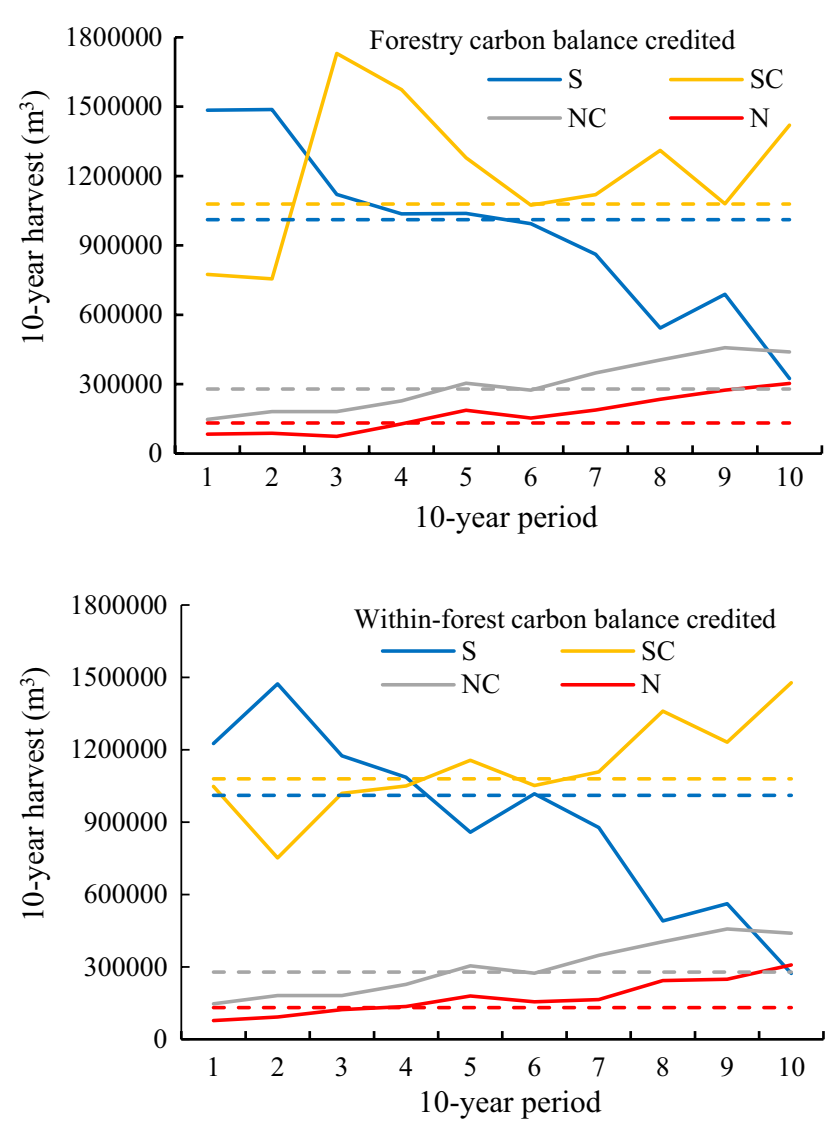

Fig. 8 Optimal harvest level in different parts of Finland when the total NPV is maximized with even-flow harvest constraints $(\geq 2.5$ million $\mathrm{m}^{3}$ in 10 years from all regions together) and carbon price is $50 € \mathrm{t}^{-1}$. Top: carbon credits are based on the total carbon balance of forestry (within-forest + products); Bottom: carbon credits are based on within-forest carbon balance (trees + soil). The dashed lines show the average harvest level when the total NPV is maximized without harvest constraints and forestry carbon balance is subsidized with $50 € \mathrm{t}^{-1} . \mathrm{S}=$ south Finland, $\mathrm{SC}=$ south-central Finland, NC=northcentral Finland, $\mathrm{N}=$ north Finland

pulpwood stems give very little income to forest landowner and pulpwood has weak carbon balance due to the high energy consumption of pulping and low substitution effects of pulp products (Hurmekoski et al. 2020).

This conclusion is also supported by the proportions of thinning from below, uniform thinning and thinning from above. Most thinning treatments selected to the optimal solutions were thinning from above, although the simulated schedules included equal areas of all three thinning types. The results suggest that it is more optimal to let the stands assigned to low-thinning regimes to grow without thinning, and clear fell them when majority of the harvested volume is saw $\log$. In these schedules, a part of the smallest trees would die. From the carbon sequestration point of view, this is not a problem since

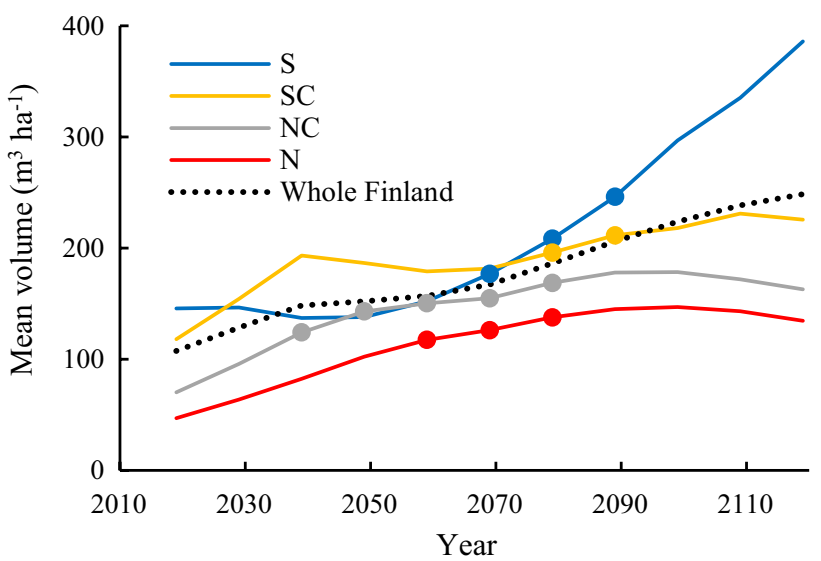

Fig. 9 Development of mean growing stock volume in different regions and in whole Finland when the total NPV (timber + carbon credits) is maximized with a $3 \%$ discount rate, carbon credits are based on the carbon balance of forestry, carbon price is $50 € \mathrm{t}^{-1}$, and a minimum of 2.5 million $\mathrm{m}^{3}$ must be harvested during every 10 -year period. The dots show the 10-year periods during which the net volume increment is the highest. $\mathrm{S}=$ south Finland, $\mathrm{SC}=$ south-central Finland, $\mathrm{NC}=$ north-central Finland, $\mathrm{N}=$ north Finland

dead pulp-wood-sized trees most probably have a better carbon balance than harvested pulp-wood-sized trees (Pukkala 2018).

The carbon pricing of this study did not follow the additionality principle where only the additional carbon sequestration, compared to the 'business as usual' (BAU) scenario, is credited. However, it might be assumed that the current carbon stocks of trees and forest soils are a result of BAU management and the stocks are at equilibrium. Since the within-forest carbon credits of this study were based on changes in the sizes of within-forest carbon pools, they might be interpreted to measure deviations from the BAU scenario. The situation is different if credits are based on the total carbon balance of forestry (products included), which is often positive even though all carbon pools are at equilibrium since the substitution effects of wood energy and wood products are higher than the releases from wood harvesting and transport, and product manufacturing. The blue lines in Fig. 5 (carbon accumulation when management is optimized without carbon credits) might be taken as estimates of forestry carbon balance under BAU management. However, they are only rough approximations since the BAU management of Finnish forests does not maximize NPV as the only objective.

The results suggest that refraining from all or almost all cuttings is optimal when carbon price is high. This would eventually lead to dense and old stands that are prone to damages. Since some damages (e.g. forest fires) greatly increase carbon releases (Couture and Reynaud 2011; van Kooten et al. 2019) and damages other than regular mortality were not simulated in the current study, it could be argued 
that the carbon balances of low-cutting scenarios were overestimated. However, the situation is not so straightforward in Finland where wildfires are rare and the biggest abiotic risk is wind damage, most of which occurs at the edges of newly clear-felled areas (Zubizarreta-Gerendiain et al. 2019). Wind thrown trees are potential starting places for severe bark beetle outbreaks. Since low cutting level decreases clear-felling, it may also have a decreasing effect on damages. In addition, large dead conifers are often rather durable carbon stores and their carbon balance may be better than that of harvested trees (Pukkala 2018).

\section{Conclusion}

The study showed that paying forest landowners $150 €$ per each ton of carbon sequestrated in forests would lead to the cessation of cuttings everywhere in Finland for at least 100 years when forests are managed for maximal discounted benefits from timber production and carbon payments. In the northern part of the country, a carbon price of $100 € \mathrm{t}^{-1}$ would suffice to make the no-cutting management economically optimal. The study also showed that, if carbon subsidies were used as policy instrument to improve the national carbon budget, low carbon price has the highest relative impact (value of increased sequestration divided by the cost of carbon payments). The benefit/cost ratio of carbon subsidies is clearly higher in the northern half of Finland (north of 64 degrees' latitude) than in the south (latitudes $60-64^{\circ}$ ). Subsidizing within-forest carbon sequestration by $50 € \mathrm{t}^{-1}$ would increase the carbon sequestration of Finnish forests by $50 \%$, ranging from $36 \%$ (south Finland) to $116 \%$ (north Finland). A payment of $100 € \mathrm{t}^{-1}$ or more would increase carbon sequestration by $70 \%$, which is nearly the maximum possible increase that can be obtained by carbon subsidies.

Acknowledgements Open access funding provided by University of Eastern Finland (UEF) including Kuopio University Hospital. This study was conducted in the FORBIO Project (Sustainable, climateneutral and resource-efficient forest-based bioeconomy), funded by the Strategic Research Council of the Academy of Finland (Decision Number 314224) at the School of Forest Sciences, University of Eastern Finland.

Open Access This article is licensed under a Creative Commons Attribution 4.0 International License, which permits use, sharing, adaptation, distribution and reproduction in any medium or format, as long as you give appropriate credit to the original author(s) and the source, provide a link to the Creative Commons licence, and indicate if changes were made. The images or other third party material in this article are included in the article's Creative Commons licence, unless indicated otherwise in a credit line to the material. If material is not included in the article's Creative Commons licence and your intended use is not permitted by statutory regulation or exceeds the permitted use, you will need to obtain permission directly from the copyright holder. To view a copy of this licence, visit http://creativecommons.org/licenses/by/4.0/.

\section{References}

Äijälä O, Koistinen A, Sved J, Vanhatalo K, Väisänen P (2014) Hyvän Metsänhoidon Suositukset-Metsänhoito (Recommendations for good forest management-forest management). Forest Development Centtre Tapio, Helsinki

Assmuth A, Tahvonen O (2018) Optimal carbon storage in even- and uneven-aged forestry. For Policy Economics 87:93-100

Assmuth A, Rämö J, Tahvonen O (2017) Economics of size-structured forestry with carbon storage. Can J For Res 48(1):11-22

Backéus S, Wikströn P, Lämås T (2006) A model for regional analysis of carbon sequestration and timber production. For Ecol Manag 216(1-3):28-40

Couture S, Reynaud A (2011) Forest management under fire risk when forest carbon sequestration has value. Ecol Econ 70(11):2002-2011

Daigneault AJ, Miranda MJ, Sohngen B (2010) Optimal forest management with carbon sequestration credits and endogeneous risk. Land Econ 86(1):155-172

Díaz-Yáñez O, Pukkala T, Packalen P, Peltola H (2019) Multifunctional comparison of different management strategies in boreal forests. Forestry. https://doi.org/10.1093/forestry/cpz053/5585603

Guthrie G, Kumareswaran D (2009) Carbon subsidies, taxes and optimal forest management. Environ Res Econ 43(2):275-293

Heinonen T, Pukkala T, Mehtätalo L, Asikainen A, Kangas J, Peltola $\mathrm{H}$ (2017) Scenario analyses for the effects of harvesting intensity on development of forest resources, timber supply, carbon balance and biodiversity of Finnish forestry. For Policy Econ 80:80-98

Helmisaari H-S, Derome J, Nöjd P, Kukkola M (2007) Fine root biomass in relation to stand characteristics in Norway spruce and Scots pine stands. Tree Physiol 27:1493-1504

Hurmekoski E, Myllyviita T, Seppälä J, Heinonen T, Kilpeläinen A, Pukkala T, Mattila T, Hetemäki L, Asikainen A, Peltola H (2020) Impact of structural changes in wood-using industries on net carbon emissions in Finland. J Ind Ecol. https://doi.org/10.1111/ jiec. 12981

Korhonen KT, Ihalainen A, Viiri H, Heikkinen J, Henttonen HM, Hotanen J-P, Mäkelä H, Nevalainen S, Pitkänen J (2013) Suomen metsät 2004-2008 ja niiden kehitys 1921-2008 (Finnish forests 2004-2008 and their development in 1921-2008). Metsätieteen aikakauskirja 3:269-608

Laasasenaho J (1982) Taper curve and volume equations for pine spruce and birch. Communicationes Instituti Forestalis Fenniae 108

Liski J, Lehtonen A, Palosuo T, Peltoniemi M, Eggers T, Muukkonen P, Mäkipää R (2006) Carbon accumulation in Finland's forests 1922-2004 - an estimate obtained by combination of forest inventory data with modelling of biomass, litter and soil. Ann For Sci 63:687-697

Liski J, Tuomi M, Rasinmäki J (2009) Yasso07 user-interface manual. Finnish Environment Institute ((www.environment.fi/syke/yasso ). 12 pp. + Appendix)

Malinen J, Kilpeläinen H, Piira T, Redsven V, Wall T, Nuutinen T (2007) Comparing model-based approaches with bucking simulation-based approach in the prediction of timber assortment recovery. Forestry 80:309-321. https://doi.org/10.1093/forestry/ cpm012

Mehtätalo L (2002) Valtakunnalliset puukohtaiset tukki-vähennysmallit männylle, kuuselle, koivuille ja haavalle [National treelevel log defect models for pine, spruce and birch]. Metsätieteen aikakauskirja 4:575-591

Minkkinen K, Laine J (1997) Effect of drainage on peat bulk density of pine mires in Finland. Can J For Res 28(2):178-186

Ojanen P (2015) Metsäojituksen vaikutuksesta ilmastoon (Climatic impacts of forestry on drained boreal peatlands). Suo 66(2):49-55 
Ojanen P, Minkkinen K, Alm J, Penttilä T (2010) Soil-atmosphere $\mathrm{CO} 2, \mathrm{CH} 4$ and $\mathrm{N} 2 \mathrm{O}$ fluxes in boreal forestry-drained peatlands. For Ecol Manag 260:411-421

Palahí M, Pukkala T, Trasobares A (2006) Calibrating predicted tree diameter distributions in Catalonia, Spain. Silva Fennica 40(3):487-500

Pohjola J, Laturi J, Lintunen J, Uusivuori J (2018) Immediate and longrun impacts of a forest carbon policy-a market level assessment with heterogeneous forest owners. J For Econ 32:94-105

Price C, Willis R (2011) The multiple effects of carbon values on optimal rotation. Journal of Forest Economics 17(3):298-306

Pukkala T (2004) Dealing with ecological objectives in the Monsu planning system. Silva Lusitana Species Issue 2004:1-15

Pukkala T (2005) Metsikön tuottoarvon ennustemallit kivennäismaan männiköille, kuusikoille ja rauduskoivikoillle. Metsätieteen aikakauskirja 3:311-322

Pukkala T (2011) Optimizing forest management in Finland with carbon subsidies and taxes. For Policy Econ 13:425-434

Pukkala T (2014) Does biofuel harvesting and continuous cover management increase carbon sequestration? For Policy Econ 43:41-50

Pukkala T (2018) Carbon forestry is surprising. For Ecosyst 5(1):11. https://doi.org/10.1186/s40663-018-0131-5

Pukkala T, Miina J (2005) Optimising the management of a heterogeneous stand. Silva Fennica 39(4):525-538

Pukkala T, Lähde E, Laiho O, Salo K, Hotanen J-P (2011) A multifunctional comparison of even-aged and uneven-aged forest management in a boreal region. Can J For Res 41:851-862

Pukkala T, Lähde E, Laiho O (2013) Species interactions in the dynamics of even- and uneven-aged boreal forests. J Sustain For 32:1-33

Raymer AK, Gobakken T, Solberg B (2011) Optimal forest management with carbon benefits included. Silva Fennica 45(3):395-414

Repola J (2009) Biomass equations for Scots pine and Norway spruce in Finland. Silva Fennica 43(4):625-647

Repola J, Ojansuu R, Kukkola M (2007) Biomass functions for Scots pine, Norway spruce and birch in Finland. Working papers of the Finnish Forest Research Institute 53

Rummukainen A, Alanne H, Mikkonen E (1995) Wood procurement in the pressure of change-resource evaluation model till year 2010. Acta Forestalia Fennica 248

Sarkkola S (ed) (2007) Greenhouse impacts of the use of peat and peatlands in Finland. Research Programme Final Report. Ministry of Agriculture and Forestry 11a/2007 ISBN 978-952-453-394-2

Sarkkola S, Hökkä H, Koivusalo H, Nieminen M, Ahti E, Päivänen J, Laine J (2010) Role of tree stand evapotranspiration in maintaining satisfactory drainage conditions in drained peatlands. Can J For Res 40:1485-1496

Seppälä J, Heinonen T, Pukkala T, Kilpeläinen A, Mattila T, Myllyviita T, Asikainen A, Peltola H (2019) Effect of increased wood harvesting and utilization on required greenhouse gas displacement factors of wood-based products and fuels. J Environ Manag 247:580-587

Siitonen M, Anola-Pukkila A, Haara A, Härkönen K, Redsven V, Salminen O, Suokas A (2001) MELA Handbook 2000 Edition. The Finnish Forest Research Institute. ISBN 951-40-1786-2

Sjølie HK, Latta G, Solberg B (2013) Potentials and costs of climate change mitigation in the Norwegian forest sector-does choice of policy matter? Can J For Res 43(6):589-598

Tuomi M, Laiho R, Repo A, Liski J (2011) Wood decomposition model for boreal forests. Ecol Model 222(3):709-718

Ťupek B, Launiainen S, Peltoniemi M, Sievänen R, Perttunen J, Kulmala L, Penttilä T, Lindroos A-J, Hashimoto S, Lehtonen A (2019) Evaluating CENTURY and Yasso soil carbon models for $\mathrm{CO}_{2}$ emissions and organic carbon stocks of boreal forest soil with Bayesian multi-model inference. Eur J Soil Sci 70(4):847-858. https://doi.org/10.1111/ejss.12805

Turunen J, Tomppo E, Tolonen K, Reinikainen A (2002) Estimating carbon accumulation rates of undrained mires in Finland-application to boreal and subarctic regions. Holocene 121:69-80

van Kooten GC, Binkley CS, Delcourt G (1995) Effect of carbon taxes and subsides on optimal forest rotation and supply of carbon services. Am J Agric Econ 77(2):365-374

van Kooten GC, Johnston CMT, Mokhtarzadeh F (2019) Carbon uptake and forest management under uncertainty: why natural disturbance mattes. J For Econ 34(1-2):159-185

Zubizarreta-Gerendiain A, Pukkala T, Peltola H (2016) Effects of wood harvesting and utilization policies on the carbon balance of forestry under changing climate: a Finnish case study. For Policy Econo 62:168-176

Zubizarreta-Gerendiain A, Pukkala T, Peltola H (2019) Effect of wind damage on the habitat suitability of saproxylic species in a boreal forest landscape. J For Res 30(3):879-889. https://doi. org/10.1007/s11676-018-0693-7

Publisher's Note Springer Nature remains neutral with regard to jurisdictional claims in published maps and institutional affiliations. 